\title{
ANALISIS KEPUTUSAN PENDANAAN TERHADAP STRUKTUR MODAL MELALUI TRADE OFF THEORY
}

\author{
NANA UMDIANA*, DYAH LUPITA SARI \\ Univer sitas Serang Raya \\ *Email: nanaumdianaunsera@gmail.com
}

\begin{abstract}
This study aims to analyze funding decisions on capital structure through trade off theory in property and real estate companies listed on the Indonesia Stock Exchange for the period 2015-2018. Profitability is measured using the return on equity ratio, asset structure is measured by fixed assets ratio and funding decisions are measured by debt. to equity ratio. The population of this research is property and real estate companies listed on the Indonesia Stock Exchange for the period 2015-2018. The data analyzed is secondary data in financial reports or annual reports. The sample selection used purposive sampling method and the sample obtained in this study were 40 data from 10 companies. In this research, the analytical method used is descriptive statistics, classical assumption test, multiple regression analysis and statistical test. The results of the analysis in this study indicate that there is no effect of profitability on funding decisions, there is an effect of asset structure on funding decisions. This shows that the asset structure influences the company's decision making in funding.
\end{abstract}

Keywords: asset structure; funding decisions; profitability

\section{PENDAHULUAN}

Perkembangan bisnis Property dan Real Estate di Indonesia saat ini dapat dikategorikan mengalami pertumbuhan yang signifikan. Hal ini dapat dilihat dari semakin maraknya pembangunan rumah hunian, apartement, perkantoran dan proyek. Perkembangan ini juga mendorong tumbuhnya pengembang-pengembang baru yang menunjukkan terus bertambahnya jumlah perusahaan setiap tahunnya pada bisnis properti. Dengan semakin pesatnya pertumbuhan di sektor Property dan Real Estate diharapkan dapat berpengaruh positif terhadap perekonomian Indonesia sehingga dapat lebih baik. Keputusan penting yang dihadapi manajer keuangan dalam kaitannya dengan keberlangsungan operasi perusahaan adalah keputusan pendanaan. Keputusan pendanaan yang tidak tepat akan menimbulkan biaya yang tinggi dan hal tersebut akan menyebabkan perusahaan memperoleh profitabilitas yang rendah. Pada beberapa perusahaan Property dan Real Estate yang terdaftar di BEI mengalami fluktuasi struktur modal perusahaan yakni mengalami peningkatan nilai DER sehingga berdampak semakin besar beban perusahaan terhadap pihak luar. 
Jurnal Ilmiah Akuntansi Universitas Pamulang - Vol. 8, No. 2, Juli 2020 - Umdiana \& Sari

Tabel 1. Struktur Modal Perusahaan Property dan Real Estate Sampel Periode 2015-2018

\begin{tabular}{clcccc}
\hline No. & $\begin{array}{c}\text { Kode } \\
\text { Perusahaan }\end{array}$ & 2015 & 2016 & 2017 & 2018 \\
\hline 1. & APLN & $155 \%$ & $137 \%$ & $141 \%$ & $142 \%$ \\
2. & ASRI & $183 \%$ & $181 \%$ & $142 \%$ & $119 \%$ \\
3. & BSDE & $63 \%$ & $58 \%$ & $57 \%$ & $72 \%$ \\
4. & FMII & $31 \%$ & $15 \%$ & $18 \%$ & $39 \%$ \\
5. & JRPT & $83 \%$ & $73 \%$ & $59 \%$ & $57 \%$ \\
\hline
\end{tabular}

Sumber : Data Olahan Laporan Keuangan

Profitabilitas merupakan kemampuan perusahaan untuk memperoleh laba dalam hubungannya dengan penjualan, total asset maupun modal sendiri. Penggunaan utang akan lebih menguntungkan apabila dibandingkan dengan penggunaan modal sendiri di dalam membiayai kegiatan perusahaan sehingga sesuai dengan trade off theory yang menjelaskan bahwa tingkat utang yang optimal tercapai ketika penghematan pajak mencapai jumlah yang maksimal terhadap biaya kesulitan keuangan teori ini mendorong perusahaan yang memiliki profitabilitas yang tinggi cenderung untuk menggunakan utang terlebih dahulu dan relatif besar dalam struktur modalnya agar mendapatkan keuntungan dari pajak. Karena menurut teori ini, pembayaran bunga utang dapat mengurangi beban pajak yang harus dibayar perusahaan sehingga ada penghematan membayar pajak. Di sisi lain, perusahaan yang memiliki tingkat keuntungan yang besar mempunyai sumber pendanaan internal yang lebih besar dan mendorong perusahaan untuk menggunakannya terlebih dahulu untuk memenuhi kebutuhan melakukan pembiayaan investasi perusahaan sehingga tingkat penggunaan utangnya atau pendanaan eksternal yang digunakan relatif kecil dan akan memperkecil resiko timbulnya kebangkrutan serta biaya utang yang tinggi. Dari penjelasan tersebut terlihat dari pendapat peneliti mengenai keputusan struktur modal dan teori-teori struktur modal yang ada masih saling bertentangan. Selain itu, struktur aktiva dalam suatu perusahaan menunjukkan perbandingan antara total asset tetap yang dimiliki oleh perusahaan dengan total asset perusahaan. Struktur aktiva merupakan nilai dari seluruh aktiva berwujud yang dapat dijadikan agunan dari pinjaman perusahaan. Bila perusahaan gagal dalam memenuhi kewajibannya, maka pihak kreditor akan menyita asset yang dijaminkan tersebut. Darminto dan Manurung (2008) serta Rajan dan Zingales (1995) menemukan bahwa struktur aktiva berpengaruh positif signifikan terhadap struktur modal. Utami (2009) dalam penelitiannya memperoleh hasil bahwa struktur aktiva mempengaruhi struktur modal perusahaan.

Penelitian mengenai faktor-faktor yang mempengaruhi struktur modal telah banyak dilakukan. Tetapi dari beberapa penelitian terdahulu, masih terdapat ketidak konsistenan hasil penelitian khususnya mengenai variabel yang diteliti yaitu pengaruh tingkat profitabilitas dan struktur aktiva terhadap struktur modal. Selain itu terdapatnya perbedaan hasil penelitian dengan teori struktur modal yang ada. Penelitian yang dilakukan oleh Indrawati (2006) menunjukkan bahwa 
Jurnal Ilmiah Akuntansi Universitas Pamulang - Vol. 8, No. 2, Juli 2020 - Umdiana \& Sari

profitabilitas berpengaruh negatif dan signifikan terhadap struktur modal, tetapi hasil penelitian ini berbeda dengan penelitian yang dilakukan oleh Wijaya dan Hadianto (2008) yang menyatakan bahwa profitabilitas berpengaruh positif dan signifikan terhadap stuktur modal. Dari hasil penelitian Wijaya dan Hadianto mengatakan bahwa perusahaan yang memiliki laba yang tinggi akan menggunakan lebih banyak utang untuk mendapatkan keuntungan yang lebih besar dari pengurangan pajak sehingga mendorong perusahaan untuk menggunakan utang terlebih dahulu untuk mendapatkan penghematan membayar pajak. Hasil penelitian ini tentu tidak sesuai dengan salah satu teori struktur modal, secara ringkas menyatakan mendorong perusahaan yang mempunyai profit yang besar untuk menggunakan dana internalnya terlebih dahulu dalam mendanai kegiatan kegiatan perusahaan sehingga tingkat penggunaan utangnya akan relatif rendah dan akan mengurangi resiko timbulnya kebangkrutan serta biaya utang yang tinggi. Hasil penelitian Seftianne dan Handayani (2011) menunjukkan bahwa struktur aktiva tidak berpengaruh terhadap struktur modal, sedangkan pada penelitian Joni dan Lina (2010), menyatakan bahwa variabel struktur aktiva berpengaruh positif signifikan terhadap struktur modal. Perusahaan yang memiliki asset tetap dalam jumlah besar cenderung menggunakan hutang lebih banyak karena aset-aset berwujud dapat dijadikan sebagai jaminan oleh perusahaaan kepada pihak eksternal sehingga perusahaan lebih mudah dalam melakukan pinjaman.

\section{LANDASAN TEORI}

\section{Trade Off Theory}

Menurut Myers (2015:481) berpendapat bahwa: “Teori trade-off adalah teori dimana perusahaan menentukan keputusan pemilihan penggunaan utang atau ekuitas sebagai pertukaran antara interest tax shield (keuntungan utang) dan biaya kebangkrutan perusahaan”. Sejalan dengan Brigham (2016:486) yang menyatakan bahwa teori trade- off adalah: "Teori struktur modal yang menyatakan bahwa perusahaan menukar manfaat pajak dari pendanaan utang dengan masalah yang ditimbulkan oleh potensikebangkrutan". Menurut pengertian teori diatas dapat disimpukan bahwa teori trade-off yaitu teori apabila perusahaan melakukan pembiayaan investasi menggunakan utang dapat diuntungkan karena manfaat dari sisi pajaknya atas pembayaran bunga yang dapat mengurangi jumlah pajak yang dibayarkan perusahaan. Dimana bunga diperhitungkan sebagai biaya dan mengurangi penghasilan kena pajak. Tetapi disamping keuntungan atas manfaat pajaknya perusahaan mempunyai resiko akan timbulnyakebangkrutan.

\section{Profitabilitas}

Profitabilitas merupakan kemampuan perusahaan untuk menciptakan laba dengan menggunakan modal yang cukup tersedia. Profitabilitas suatu perusahaan akan berpengaruh terhadap kebijakan perusahaan dalam menentukan pendanaannya. Menurut Kasmir (2015: 196), profitabilitas adalah: "Rasio yang digunakan untuk menilai kemampuan perusahaan dalam mencari keuntungan. 
Jurnal Ilmiah Akuntansi Universitas Pamulang - Vol. 8, No. 2, Juli 2020 - Umdiana \& Sari

Rasio ini juga memberikan ukuran tingkat efektivitas manajemen suatu perusahaan. Hal ini ditunjukkan oleh laba yang dihasilkan dari penjualan dan pendapatan investasi. Penggunaan rasio profitabilitas dapat dilakukan dengan menggunakan perbandingan antara berbagai komponen yang ada di laporan keuangan, terutama laporan keuangan neraca dan laporan laba rugi”. Menurut Brigham dan Houston yang dialihbahasakan oleh Ali Akbar Yulianto (2011: 146): "Profitabilitas adalah sekelompok rasio yang menunjukkan kombinasi dan pengaruh likuiditas, manajemen aset dan utang pada hasil operasi". Berdasarkan beberapa definisi di atas makas dapat disimpulkan bahwa profitabilitas merupakan kemampuan perusahaan dalam mengahasilkan laba dengan aktiva dan modal yang dimilikinya.

\section{Sruktur Aktiva}

Struktur aktiva perusahaan memainkan peranan penting dalam menentukan pembiayaan perusahaan. Perusahaan yang memiliki aset tetap jangka panjang yang tinggi, dikarenakan permintaan akan produk mereka tinggi. Hal tersebut akan mengakibatkan penggunaan utang jangka panjang. Perusahaan yang sebagian aktivanya berupa piutang dan persediaan barang yang nilainya sangat tergantung pada kestabilan tingkat profitabilitas, tidak terlalu tergantung pada pembiayaan jangka pendek. Adapun definisi struktur aset menurut beberapa ahli diantaranya adalah sebagai berikut : Menurut Lukman Samsuddin (2011:9) bahwa : "Struktur aktiva adalah penentuan berapa besar alokasi dana untuk masing-masing komponen aktiva, baik dalam aktiva lancar maupun aktiva tetap". Menurut Bambang Riyanto (2011:22) Struktur Aktiva atau struktur kekayaan adalah perimbangan atau perbandingan baik dalam artian absolut maupun dalam artian relatif antara aktiva lancar dengan aktiva tetap, yang dimaksud dengan artian absolut adalah perbandingan dalam bentuk nominal, sedangkan yang dimaksud dengan relatif adalah perbandingan dalam bentuk persentase. Menurut Subramanyam dan Wild (2012:271) mengartikan aktiva sebagai aset, aset merupakan: "Sumber daya yang dikuasai oleh suatu perusahaan dengan tujuan menghasilkan laba". Dari penjelasan diatas dapat disimpulkan bahwa aktiva atau aset adalah segala sumber daya dan harta yang dimiliki perusahaan untuk digunakan dalam operasionalnya. Suatu perusahaan pada umumnya memiliki dua jenis aktiva yaitu aktiva lancar dan aktiva tetap. Kedua unsur aktiva ini akan membentuk struktur aktiva. Strukrur aktiva juga disebut struktur aset atau struktur kekayaan pada perusahaan yang akan tampak dalam sisi sebelah kiri neraca.

\section{Keputusan Pendanaan}

Sumber dana dapat dibedakan menjadi sumber intern dan sumber extern. Dana yang berasal dari intern adalah dana atau modal yang dibentuk atau dihasilkan sendiri didalam perusahaan seperti laba ditahan dan penyusutan. Sumber dana extern adalah sumber dana yang berasal dari luar perusahaan, yang berasal dari para kreditur dan pemilik, peserta atau pengambil bagian dalam perusahaan.Keputusan pendanaan ini sering disebut sebagai kebijakan struktur modal. Pada keputusan ini 
Jurnal Ilmiah Akuntansi Universitas Pamulang - Vol. 8, No. 2, Juli 2020 - Umdiana \& Sari

manajer keuangan dituntut untuk mempertimbangkan dan menganalisis kombinasi dari sumber-sumber dana yang ekonomis bagi perusahaan guna membelanjai kebutuhan-kebutuhan investasi serta kebutuhan usahanya. Menurut Kasmir (2010:6) bahwa: "Keputusan Pendanaan merupakan keputusan yang berkaitan dengan jumlah dana yang disediakan perusahaan baik yang bersifat utang atau modal sendiri". Menurut Sudana (2011:3) bahwa: "Keputusan pendanaan adalah keputusan keuangan tentang asal dana untuk membeli aktiva. Ada dua macam sumber dana: (1) dana pinjaman, seperti utang bank dan obligasi (2) modal sendiri, seperti laba ditahan dan saham. Dana pinjaman dan saham, merupakan sumber dana yang berasal dari luar perusahaan, sedangkan laba ditahan merupakan sumber dana yang berasal dari dalam perusahaan". Sedangkan menurut Van Horne et al (2009:3): "Keputusan pendanaan ini sering disebut juga sebagai kebijakan struktur modal. Pada keputusan ini manajer keuangan dituntut untuk mempertimbangkan dan menganalisis kombinasi dari sumber-sumber dana yang ekonomis bagi perusahaan guna membelanjai kebutuhan-kebutuhan investasi serta kegiatan usahanya". Berdasarkan definisi di atas maka dapat disimpulkan bahwa keputusan pendanaan merupakan keputusan yang berkaitan dengan penentuan sumber dana yang digunakan dan penentuan pertimbangan yang terbaik atau penentuan sumber optimal.

\section{Hipotesis Penelitian}

Profitabilitas terhadap keputusan pendanaan

Profitabilitas digunakan untuk mengukur kemampuan perusahaan dalam menghasilkan laba. Tingkat profitabilitas memperlihatkan kemampuan perusahaan untuk mendapatkan keuntungan atas investasi maupun kegiatan operasional perusahaan. Apabila laba yang dihasilkan sedikit, perusahaan cenderung akan menggunakan hutang sebagai pendanaan dalam kegiatan operasional bisnisnya. Semakin tinggi laba yang dihasilkan suatu perusahaan akan meningkatkan kepercayaan kreditur untuk memberikan pinjaman dan dapat meningkatkan kepercayaan investor untuk menanamkan modal. Terdapat perbedaan pendapat dari penelitian terdahulu. Hasil penelitian yang dilakukan, Aisha Abdullah (2013), Jemmi (2013), Trisna Hayuning (2010) berpendapat bahwa profitabilitas berpengaruh signifikan terhadap struktur modal. Namun bertentangan dengan penelitian yang dilakukan Steftianne dan Ratih Handayani (2012) bahwa profitabilitas tidak berpengaruh signifikan terhadap struktur modal. Berdasarkan penelitian-penelitian tersebut, dapat diajukan hipotesis mengenai pengaruh profitabilitas terhadap keputusan pemdanaan perusahaan sebagai berikut: Profitabilitas berpengaruh terhadap Keputusan Pendanaan

\section{Struktur aktiva terhadap keputusan pendanaan}

Struktur aktiva menggambarkan sebagian jumlah aset yang dapat dijadikan jaminan. Komponen Struktur aktiva yaitu aktiva lancar dan aktiva tetap. Dalam penelitian yang dilakukan Seftianne dan Ratih (2011) menunjukkan bahwa struktur aktiva tidak berpengaruh terhadap struktur modal. Penelitian yang dilakukan oleh 
Jurnal Ilmiah Akuntansi Universitas Pamulang - Vol. 8, No. 2, Juli 2020 - Umdiana \& Sari

Trisna (2010) menunjukkan bahwa struktur aktiva berpengaruh positif terhadap struktur modal. Penelitian yang dilakukan oleh Jemmi, Werner, Bertha (2013) menunjukkan bahwa struktur aktiva berpengaruh positif signifikan terhadap struktur modal. Berdasarkan penelitian-penelitian tersebut, dapat diajukan hipotesis mengenai pengaruh struktur aktiva terhadap keputusan pendanaan perusahaan sebagai berikut: Struktur Aktiva berpengaruh terhadap Keputusan Pendanaan.

\section{METODOLOGI PENELITIAN}

Metode penelitian yang dilakukan dalam penelitian ini adalah penelitian asosiatif. Penelitian asosiatif adalah penelitian yang bertujuan untuk mengetahui hubungan antara dua variabel atau lebih, metode ini bersifat untuk menjelaskan, meramalkan, dan mengontrol segala peristiwa. Pada penelitian asosiatif ini dengan menggunakan pendekatan kuantitatif. Penelitian kuantitatif adalah penelitian akan memperoleh data yang berbentuk angka atau data kualitatif yang diangkakan (Sugiyono,2017:7).

\section{Populasi dan Sampel}

Populasi berarti objek yang dijadikan penelitian. Populasi yang digunakan dalam penelitian ini adalah perusahaan manufaktur subsektor makanan dan minuman yang terdaftar di Bursa Efek Indonesia periode 2013-2018 sebanyak 18 perusahaan. Teknik pengambilan sample dalam penelitian ini menggunakan proposive sampling, Teknik pengambilan sampel purposive sampling yaitu sampel diambil berdasarkan kriteria tertentu sesuai dengan tujuan penelitian yang dianggap mewakili populasi.

\section{Definisi Operasional Variabel dan Pengukurannya}

Variabel Dependen

Variabel terikat atau variabel dependen merupakan variabel yang dipengaruhi atau yang menjadi akibat, karena adanya variabel bebas (Sugiyono, 2017;39). Variabel terikat dalam penelitian ini yaitu Keputusan Pendanaan (Y) diukur dengan Debt equity Ratio. Definisi Keputusan pendanaan menurut Kasmir (2010: 16): "Keputusan Pendanaan merupakan keputusan yang berkaitan dengan jumlah dana yang disediakan perusahaan baik yang bersifat utang atau modal sendiri." Keputusan pendanaan diukur menggunakan rumus sebagai berikut :

$$
\mathrm{DER}=
$$

Variabel Independen

Variabel independen merupakan variabel yang mempengaruhi atau yang menjadi sebab perubahannya atau timbulnya variabel dependen atau variabel terikat (Sugiyono, 2017;39). Dalam penelitian ini variabel independen yang akan diteliti adalah Profitabilitas (X1) dan Struktur Aktiva (X2). Definisi profitabilitas menurut Kasmir (2015: 199): "Rasio yang digunakan untuk menilai kemampuan perusahaan dalam mencari keuntungan." Profitabilitas diukur menggunakan rumus sebagai berikut : 
Jurnal Ilmiah Akuntansi Universitas Pamulang - Vol. 8, No. 2, Juli 2020 - Umdiana \& Sari

$$
\mathrm{ROE}=
$$

Definisi struktur aktiva menurut Bambang Riyanto (1022: 22): "Struktur Aktiva atau struktur kekayaan adalah perimbangan atau perbandingan baik dalam artian absolut maupun dalam artian relatif antara aktiva lancar dengan aktiva tetap, yang dimaksud dengan artian absolut adalah perbandingan dalam bentuk nominal, sedangkan yang dimaksud dengan relatif adalah perbandingan dalam bentuk presentase." Struktur aktiva diukur menggunakan rumus sebagai berikut :

\section{Struktur Aktiva $=$}

Teknik Analisis Data

Proses analisis data dalam penelitian ini adalah dengan mengolah data dengan menggunakan aplikasi SPSS ( Statistical Product and Service Solustion ) Versi 25, dan teknik analisis data ini menggunakan regresi linier berganda.

\section{HASIL PENELITIAN DAN PEMBAHASAN}

Hasil Penelitian

Statistik Deskriptif

Uji statistik deskriptif dalam penelitian ini digunakan untuk melihat nilai minimum, maksimum, mean dan satndar deviasi , adapun hasil dari uji statistik deskriptif adalah sebagai berikut :

Tabel 1.

\begin{tabular}{lrrrrr}
\hline & N & Minimu & Maximu & \multicolumn{1}{c}{ Mean } & \multicolumn{1}{c}{ Std. } \\
\hline Profitabilitas & 35 & .37 & 21.00 & 11.7217 & 5.54336 \\
Struktur Aktiva & 35 & .03 & 31.48 & 7.3263 & 6.44171 \\
Keputusan Pendanaan & 35 & 9.21 & 183.38 & 93.5266 & 48.08828 \\
Valid N (listwise) & 35 & & & & \\
\hline
\end{tabular}

Berdasarkan pengolahan data variabel independen profitabilitas mempunyai nilai minimum 0,37 dan nilai maksimum sebesar 21,00 Nilai rata-rata sebesar 11,7217 dan nilai standar deviasi sebesar 5,54336. Nilai rata-rata yang lebih besar dibandingkan dengan nilai standar deviasi menunjukan bahwa nilai berdistribusi baik.

Berdasarkan pengolahan data variabel Independen struktur aktiva mempunyai nilai minimum 0,03 dan nilai maksimum sebesar 31,48. Nilai rata-rata sebesar 7,3263 dan nilai standar deviasi sebesar 6,44171. Nilai rata-rata yang lebih besar dibandingkan dengan nilai standar deviasi menunjukan bahwa nilai berdistribusi baik. 
Jurnal Ilmiah Akuntansi Universitas Pamulang - Vol. 8, No. 2, Juli 2020 - Umdiana \& Sari

Berdasarkan pengolahan data variabel dependen keputusan pendanaan nilai minimum 9,21 dan nilai maksimum sebesar 183,38. Nilai rata-rata sebesar 93,5266 dengan Standar Deviasi sebesar 48,08828. Standar Deviasi yang lebih kecil dari mean menunjukan besaran data yang lebih kecil antara keputuan pendanaan terendah dan tertinggi. Sehingga, dapat disimpulkan data yang digunakan merupakan data yang baik.

Uji Asumsi Klasik

Uji Normalitas

Berdasarkan hasil nilai kolmogorof smirnov dengan melihat signifikan 0,200. Hal ini berarti data residual berdistribusi normal. Dapat dibuktikan dari nilai signifikansi sebesar 0,200 lebih besar dari $0,05(0,200>0,05)$.

\section{Uji Multikolinieritas}

Dari hasil uji multikolinieritas apabila nilai Variance Inflation Factor (VIF) dibawah 10 dan nilai Tolerance $>$ 0,10 dan nilai VIF dibawah 10 dengan demikian dapat disimpulkan tidak ada multikolonieritas variabel dalam penguji ini.

\section{Uji Heteroskedastitas}

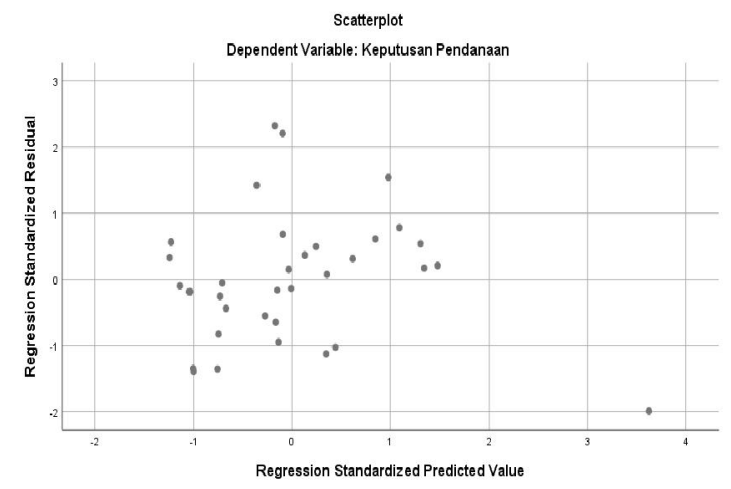

Gambar 1. Scatterplot

Berdasarkan output scatterplot gambar regresi di atas bahwa tidak terjadi heteroskedastitas terlihat titik-titik data menyebar diatas dan di bawah atau sekitar angka nol titik-titik data tidak mengumpul hanya atas dan bawah, dan penyebaran titik-titik tidak berpola.

\section{Uji Autokorelasi}

Berdasarkan nilai Durbin-Watson sebesar 0,798. Sesuai dengan teori menurut diatas yang menyebutkan bahwa "Jika angka D-W antara -2 sampai dengan +2 , berarti tidak ada autokorelasi. Berdasarkan hasil yang ada asumsi tidak terjadinya autokorelasi karena nilai DW menunjukkan berada di antara -2 sampai +2 yaitu sebesar 0,798 . 
Jurnal Ilmiah Akuntansi Universitas Pamulang - Vol. 8, No. 2, Juli 2020 - Umdiana \& Sari

Analisis Regresi Linier Berganda

Berdasarkan hasil pengujian diperoleh persamaan regresi linier berganda adalah sebagai berikut:

$$
\mathrm{Y}=\mathrm{a}+\mathrm{b} 1 \mathrm{X} 1+\mathrm{b} 2 \mathrm{X} 2+\mathrm{e}
$$

Keputusan Pendanaan $=73,770-0,881 \mathrm{ROE}+4,106 \mathrm{SA}+\mathrm{e}$

Persamaan regresi linier berganda menghasilkan nilai konstanta $(\sigma)$ sebesar $=73,770$ artinya jika profitabilitas dan struktur aktiva nilainya 0 . Maka besarnya keputusan pendanaan (Y) sebesar konstanta nya yaitu 73,770. Nilai koefisien dari profitabilitas (X1) bernilai negatif sebesar -0,881. Artinya, setiap penambahan $1 \%$ profitabilitas akan mengalami penurunan keputusan pendanaan sebesar $-0,881$. Dengan asumsi bahwa tidak adanya variabel lain. Nilai koefisien dari struktur aktiva (X2) bernilai positif sebesar 4,106. Artinya setiap perusahaan menambah $1 \%$ struktur aktiva akan menambahkeputusan pendanaan sebesar 4,106. Dengan asumsi bahwa tidak adanya variabel lain.

Uji Hipotesis

Uji Koefisien Regresi Secara Parsial (Uji t)

Tabel 2.

\begin{tabular}{llrrr}
\hline Model & \multicolumn{2}{c}{$\begin{array}{c}\text { Standardized } \\
\text { Beta }\end{array}$} & $\mathrm{t}$ & Sig. \\
\hline 1 & (Constant) & & 3.922 & .000 \\
& Profitabilitas & -.102 & -.695 & .492 \\
& Struktur Aktiva & .550 & 3.765 & .001 \\
\hline
\end{tabular}

Berdasarkan tabel di atas dapat diuraikan bahwa variabel profitabilitas memiliki tingkat signifikan (Sig t) sebesar 0,492 dengan nilai $t$ hitung sebesar -0,695 dan berdasarkan tabel distribusi $t$ diperoleh $t$ tabel sebesar 2,021 karena $t$ hitung $<t$ tabel $(-0,695<2,021)$ dan nilai sig sebesar 0,492 lebih besar dari $0,05(0,492>0,05)$ maka dapat disimpulkan bahwa $\mathrm{H}_{1}$ ditolak. Artinya Profitabilitas tidak berpengaruh terhadap Keputusan Pendanaan. Berdasarkan tabel di atas dapat diuraikan bahwa variabel struktur aktiva memiliki tingkat signifikan (Sig t) sebesar 0,001 dengan nilai $\mathrm{t}$ hitung sebesar 3,765 dan berdasarkan tabel distribusi $\mathrm{t}$ diperoleh $\mathrm{t}$ tabel sebesar 2,021 . Karena $t_{\text {hitung }}>t$ tabel $(3,765>2,021)$ dan nilai Sig sebesar 0,001 kurang dari $0,05(0,020<0,05)$ maka dapat disimpulkan bahwa $\mathrm{H}_{2}$ diterima. Artinya stuktur aktiva berpengaruh terhadap Keputusan Pendanaan.

\section{Uji Koefisien Determinasi (Uji R ${ }^{2}$ )}

Berdasarkan hasil perhitungan diperoleh nilai koefisien determinasi $\left(\mathrm{R}^{2}\right)$ sebesar 0,323 . Hal ini berarti menunjukan bahwa besaran presentasi keputusan 
Jurnal Ilmiah Akuntansi Universitas Pamulang - Vol. 8, No. 2, Juli 2020 - Umdiana \& Sari

pendanaan yang dijelaskan oleh variabel dari kedua variabel bebas yaitu profitabilitasdanstruktur aktivasebesar $32,3 \%$. Sedangkan sisanya dijelaskan oleh faktor lain yang tidak dimasukan dalam penelitian ini.

\section{PEMBAHASAN}

Pengaruh Profitabilitas terhadap Keputusan Pendanaan

Berdasarkan hasil uji t, menunjukan bahwa variabel profitabilitas memiliki tingkat signifikan (Sig t) sebesar 0,492 dengan nilai $t$ hitung sebesar -0,695 dan berdasarkan tabel distribusi $\mathrm{t}$ diperoleh $\mathrm{t}$ tabel sebesar 2,021 karena $\mathrm{t}$ hitung $<\mathrm{t}$ tabel ($0,695<2,021)$ dan nilai sig sebesar 0,492 lebih besar dari 0,05 $(0,492>0,05)$ maka dapat disimpulkan bahwa $\mathrm{H}_{1}$ ditolak. Artinya Profitabilitas tidak berpengaruh terhadap Keputusan Pendanaan. Hasil penelitian membuktikan profitabilitas tidak akan menjadi pertimbangan apakah perusahaan akan menggunakan dana eksternal atau tidak, tinggi atau rendahnya profitabilitas pada perusahaan property dan real estate tidak mempengaruhi keputusan pendanaan yang dilakukan oleh manager meskipun hasil penelitian tidak berpengaruh dalam hal ini dapat dilihat perilaku perusahaan sejalan dengan trade off theory yang menyatakan pendanaan menggunakan utang pun mempunyai dampak negatif terhadap perusahaan, dalam penelitian ini hasil profitabilitas pada perusahaan property dan real estate menunjukkan bahwa perusahaan tersebut kemungkinan mengalami risiko kebangkrutan akibat pendanaan dari eksternal, menurut Brigham (2016:487), jika perusahaan telah melebihi batas atas pendanaan utang, maka biaya yang berhubungan dengan kebangkrutan melebihi manfaat pajak sehingga saat titik ini mengalami peningkatan rasio utang karena risiko kebangkrutan perusahaan semakin tinggi. Hasil penelitian ini mendukung hasil penelitian yang dilakukan oleh Seftianne dan Ratih Handayani (2011), Mega Oksha Wijaya dan Muhammad Rivandi (2018) yang menunjukkan bahwa tidak ada pengaruh antara profitabilitas terhadap keputusan pendanaan. Hasil penelitian ini tidak mendukung hasil penelitian Aisha Abdullah (2013), Jemmi (2013), Trisna Hayuning (2010) berpendapat bahwa profitabilitas berpengaruh signifikan terhadap keputusan pendanaan bahwa profitabilitas berpengaruh terhadap keputusan pendanaan. Perbedaan hasil penelitian ini dimungkinkan terjadi karena adanya perbedaan dalam pemilihan sampel dan waktu penelitian.

\section{Pengaruh Struktur Aktiva terhadap Keputusan Pendanaan}

Berdasarkan hasil uji t, menunjukan bahwa variabel struktur aktiva memiliki tingkat signifikan (Sig t) sebesar 0,001 dengan nilai t hitung sebesar 3,765 dan berdasarkan tabel distribusi $\mathrm{t}$ diperoleh $\mathrm{t}$ tabel sebesar 2,021. Karena $\mathrm{t}$ hitung $>\mathrm{t}$ tabel $(3,765>2,021)$ dan nilai Sig sebesar 0,001 kurang dari $0,05(0,020<0,05)$ maka dapat disimpulkan bahwa $\mathrm{H}_{2}$ diterima. Artinya struktur aktiva berpengaruh terhadap Keputusan Pendanaan. Hasil pengujian hipotesis menyatakan bahwa struktur aktiva berpengaruh pada keputusan pendanaan. Pada perusahaan property dan real estate menggunakan posisi aset tetap sebagai dasar dalam pengambilan hutang. Hal ini 
Jurnal Ilmiah Akuntansi Universitas Pamulang - Vol. 8, No. 2, Juli 2020 - Umdiana \& Sari

bertolak belakang dengan trade off theory karena kecenderungan manajemen akan berhati-hati dalam menggunakan dan membuat kebijakan utang baru, agar kewajiban perusahaan akan semakin kecil. Semakin tinggi struktur aktiva (semakin besar jumlah aktiva tetap) maka penggunaan modal sendiri akan semakin tinggi, dan penggunaan modal asing akan semakin sedikit atau keputusan pendanaan semakin rendah. Penggunaan aset perusahaan property dan real estate menggunakan aset perusahaan untuk mengurangi pengambilan keputusan dalam melakukan pinjaman perusahaan. Aset yang lebih banyak lebih efisien memanfaatkan aset perusahaan dalam kegiatan operasional perusahaan. Perusahaan yang memerlukan dana memanfaatkan aset untuk dijual. Menurut Lukman Samsuddin (2011:9) bahwa Struktur aktiva adalah penentuan berapa besar alokasi dana untuk masing-masing komponen aktiva, baik dalam aktiva lancar maupun aktiva tetap. Hasil penelitian ini mendukung penelitian Aisha Abdullah (2015), Mega Oksha Wijaya dan Muhammad Rivandi (2018) yang menyatakan struktur aktiva berpengaruh terhadap keputusan pendanaan.

\section{KESIMPULAN}

Berdasarkan hasil dan analisis data yang telah dikemukakan pada bab sebelumnya maka dapat diambil kesimpulan sebagai berikut: Profitabilitas tidak berpengaruh rehadap keputusan pendanaan. Hal tersebut dikarenakan profitabilitas tidak akan menjadi pertimbangan apakah perusahaan akan menggunakan dana eksternal atau tidak. Struktur aktiva berpengaruh terhadap keputusan pendanaan. Hal ini dikarenakan pada perusahaan property dan real estate menggunakan posisi asset tetap sebagai dasar dalam pengambilan hutang. Penelitian selanjutnya sebaiknya menambah jumlah variabel atau menggunakan variabel independen lain yang mempengaruhi keputusan pendanaan atau struktur modal seperti ukuran perusahaan, keadaan pasar, struktur kepemilikan dan lain - lain. hal ini dikarenakan dari nilai determinasi (R2) hanya mampu dijelaskan sebesar 32,3\% atau dengan kata lain $67,7 \%$ keputusan pendanaan dipengaruhi oleh variabel lain diluar model penelitian ini.

\section{DAFTAR PUSTAKA}

Abdullah, Aisha. (2015). Jurnal Akuntansi : "Pengaruh Trade Off Theory dan Pecking Order TheoryTerhadap Struktur Modal Perusahaan Yang Terdaftar di Index LQ45 Periode 2010-2014".

Al Ashry, Lara. dan Harkadri Fitra. (2019). "Pengaruh Pertumbuhan Penjualan dan Profitabilitas Terhadap Struktur Modal pada Perusahaan Real Estate and Property di bursa Efek Indonesia". Jurnal Kajian Manajemen dan Wirausaha. Vol 01 nomor 012019. 
Jurnal Ilmiah Akuntansi Universitas Pamulang - Vol. 8, No. 2, Juli 2020 - Umdiana \& Sari

Brigham, Eugene F. dan Joel F. Houston. (2016). Fundamentals of Financial Management (Dodo Suharto dan Hermawan Wibowo, Penerjemah). Edisi 8. Jakarta: Erlangga.

Calisir et al. (2010). "Jurnal Analisis Pengaruh Struktur Modal, Ukuran Perusahaan, dan Agency Cost Terhadap Kinerja Keuangan".

Darmayanti. (2013). Jurnal Akuntansi : "Pengaruh Profitabilitas, Pertumbuhan Aktiva dan Struktur Aktiva Terhadap Keputusan Pendanaan Pada Perusahaan Oders di BEI".

Dewani,Trisna Hayuning. (2010) “Analisis Faktor-Faktor yang Mempengaruhi Struktur Modal (Studi Perbandingan Pada Perusahaan Aneka Industri dan ConsumerGoods Periode 2007-2009)".

Ghozali, Imam. (2018). Aplikasi Analisis Multivariative dengan Program SPSS. Semarang: Badan Penerbit Universitas Diponegoro.

Hanafi, Mamduh M. dan Abdul Halim. (2005). Analisis Laporan Keuangan.Edisi Kedua. Yogyakarta: UPP AMP YKPN.

Hossain, Faruk and Ayub Ali (2012) "Impact of Firm Specific Factors on Capital Structure Decision: An Empirical Study of Bangladeshi Companies". Tujuan penelitian ini adalah To identify the firm specific factors affecting capital structure decisions of listed firms in Dhaka Stock Exchange

Ibrahim Fenandar, Gany. (2012). Jurnal Akuntansi : "Pengaruh Keputusan Investasi, Keputusan Pendanaan, dan Kebujakan Deviden Terhadap Nilai Perusahaan".

Kasmir, (2013). Analisis Laporan Keuangan. Jakarta : Rajawali Pers

Kusumajaya. (2011). Jurnal Akuntansi : "Pengaruh Struktur Modal \& Pertumbuhan Perusahaan terhadap Profitabilitas \& nilai perusahaan pada perusahaan manufaktur di Bursa Efek Indonesia"

Liem, Jemmi Halim, Werner R. Muhadi, Bertha Silvia Sutejo (2013) “Analisis Faktor-Faktor Yang Mempengaruhi Struktur Modal Pada Industri Consumer Goods Yang Terdaftar di BEI Periode 2007-2011”.

Mutamimah dan Rita. (2009). "Keputusan Pendanaan : Pendekatan Trade Off Theory dan Pecking Order Theory".EKOBISVol.10, No.1, Januari 2009 : $241-249$

Riyanto, Bambang. (2011). Dasar-Dasar Pembelanjaan Perusahaan. Yogyakarta: BPFE.

Rudianto. 2006. Akuntansi Manajemen: Informasi untuk Pengambilan Keputusan Manajemen. Jakarta: PT Gramedia Widiasarana Indonesia.

Santoso, Singgih (2018). Menguasai Statistik dengan SPSS 25. Jakarta: PT Elex Media Komputindo

Seftianne. dan Ratih Handayani (2011) "Faktor-faktor yang Mempengaruhi Struktur Modal Pada Perusahaan Publik Sektor Manufaktur". 
Jurnal Ilmiah Akuntansi Universitas Pamulang - Vol. 8, No. 2, Juli 2020 - Umdiana \& Sari

Silfia, Siska. (2014). Pengaruh Profitabilitas, Struktur Aktiva, Pertumbuhan Perusahaan, Pajak, dan Pertumbuhan Penjualan Terhadap Keputusan Pendanaan Pada Perusahaan Real Estateand Property Periode Tahun 20112013. Fakultas Ekonomi. Universitas Maritim Raja Ali Haji. TanjungPinang.

Sugiyono, 2012. Memahami Penelitian Kuantitatif. Bandung : Alfabeta

Yuliani, Irene. 2017. Jurnal Akuntansi: "Pengaruh Struktur Modal dan Kepemilikan Manajerial terhadap Kinerja Perusahaan dengan Agency Cost sebagai variabel intervening."

www.idx.co.id 